\title{
Transnational Tongan life
}

\author{
TEENA BROWN \& RICHARD PAMATATAU
}

As a branch of migration studies, transnational studies explores how migrants stay connected to the old country by keeping up loyalties to the homeland where they were born and still have kinfolk still living. The trans signifies patriotism for more than one country. Migrants are devoted to places of residence where they work, live and raise families, and also to the places and peoples from which they have permanently moved. Helen Lee offers a broad-spectrum definition by proposing that 'For Pacific Islanders, transnationalism involves the multidirectional movement of people, money, goods of many different kinds, artefacts, ideas and symbols' (2009:1). According to this approach, transnationalism is about the upward mobility of people in a system of global capitalism, and the flexibility to move from one place to another. Lee writes little, however, to characterize how Pacific transnationalism is distinctive from that of other regions.

Sa'iliemanu Lilomaiava-Doktor has contextualized the culturallyspecific meaning of Samoan transnationalism with respect to Salelologa village on Savai'i island and its diasporic settlements in Santa Ana (a suburb of Los Angeles in California), and Auckland, in New Zealand. In her view, the village could not be examined as 'the only core and centre for its 'aiga [kinfolk], [as] there are now multiple centres' that have emerged in the overseas cities of Auckland, Sydney and Los Angeles where villagers migrated, settled and have raised their New Zealandborn, Australian-born and American-born descendants (2009:60).

The trans in transnational, signifying migrant loyalties to more than one country, had mutated with generations born overseas. It seems pertinent to say that, in one way, the homeland and diaspora are dependent on the exchange of people and goods to preserve the relationship between them, which sustains an informal system of economies and networks. The difference between the two is that the populations of Pacific Islanders in Auckland, Sydney and Los Angeles have expanded from isolated migrant clusters to what Walter J. Nicholls and Justus Uitermark have described as 'Migrant Cities' (2016:877). In relation to certain suburbs or migrant cities, therefore, Pacific Islanders are the majority of the public, despite being an ethnic minority in the country.

On that note Nancy Fraser's (1990) idea of counterpublic, defined as an alternative public, interests us - Teena Brown, an anthropologist, and Richard Pamatatau, a journalist. The contents of our own lives have made
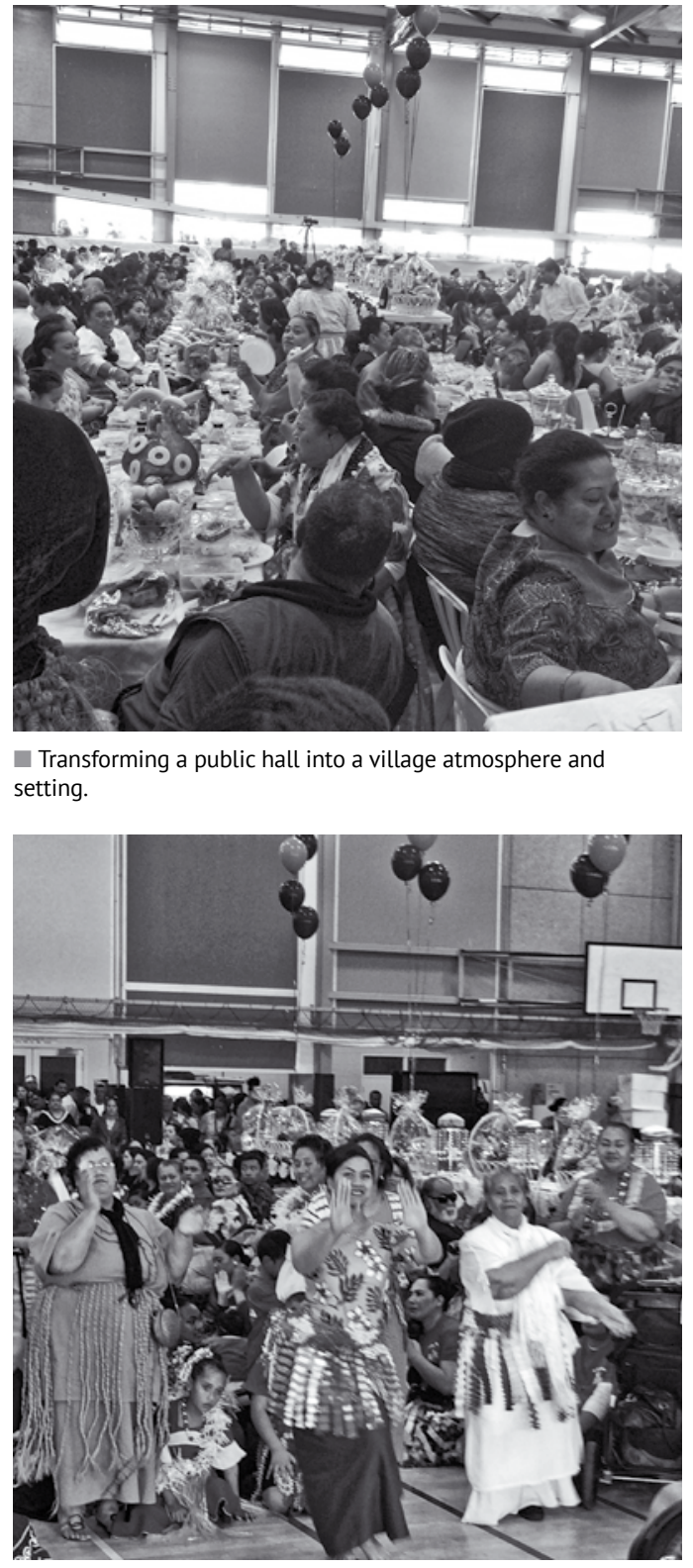

Transferring Tongan cultural performance from Tonga to Otahuhu, South Auckland. 


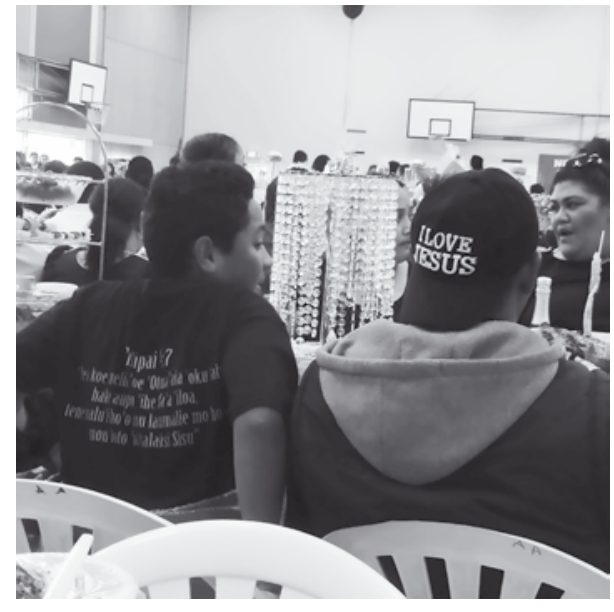

Transmission of religious messages by an ethnic group who are church-going Christians.

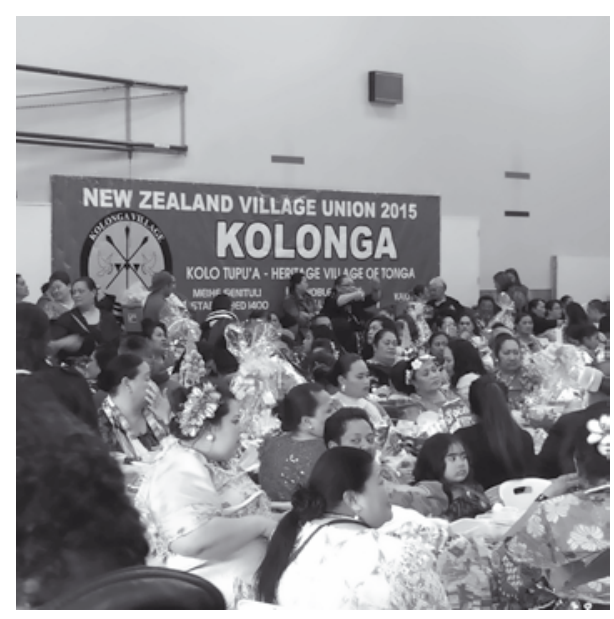

Transporting Kolonga, the village in Tonga, to a new location, the village in New Zealand.

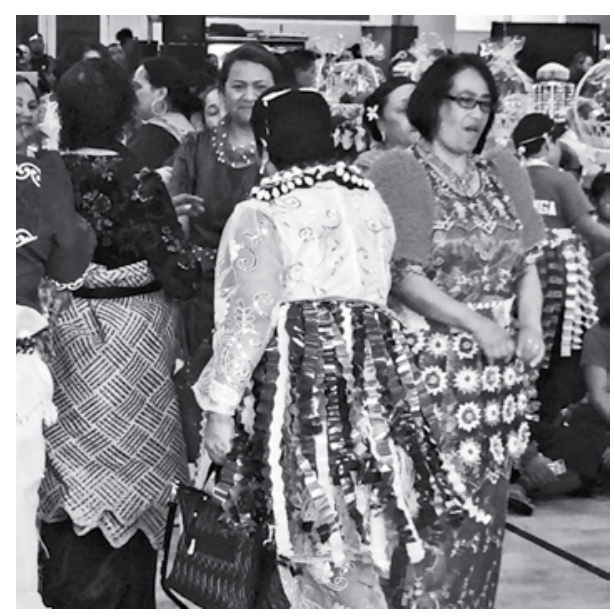

Transfixed by Tongan costume that mixes natural materials - woven mats, coconut rope and seashells with plastic, paper and synthetic cloth. for fascinating research in that Teena traces her Pacific Islander ancestry to Tonga, and Richard to the Cook Islands. We were both born and raised in New Zealand, and work and live in Auckland, a migrant city home to a third of the national population. How are counterpublics manufactured by ethnic groups who are busy transforming cities of Western developed countries? In every aspect the counterpublic is plural by content and nature, and is the result of exclusion by the dominant public, which in our case, as Auckland Pacific Islanders, is the Palangi - the white and English-speaking public.

Counterpublics respond to 'the exclusionary nature of the dominant public' by transplanting social institutions that represent and serve them and their communities - churches, cultural associations, Pacific language kindergartens, newspapers, radio shows, media outlets, businesses specializing in island foods and catering for festivities - to residential suburbs (Nicholls and Uitermark 2016:880). Pacific Islander counterpublics in the South Auckland suburbs of Otahuhu, Mangere and Otara, for example, are creating socially inclusive places and events to neutralize the way in which, in other areas of the city, the dominant public not only discounts the Pacific Islands and its peoples, but also keeps them out of the public sphere.

To address these cultural transformations, we present a photographic essay playing on the trans in transnational while speaking to the question: What is a transnational Tongan life? An aspect of the counterpublic in Otahuhu, a South Auckland suburb where Tongan migrants and their New Zealandborn children, grandchildren and great-grandchildren are the main ethnic sub-population, is celebrating the Tongan holiday of village day. Tonga is a constitutional monarchy of 105,000 Polynesians, and comprises 176 coral atolls. Having assumed the throne in 2012, King Tupou VI is the Head of State and the Commander-in-Chief of His Majesty's Armed Forces. In the Pacific Rim diaspora communities of Auckland, Sydney and Los Angeles, where most Tongans live, village day symbolizes island roots and city routes. Diasporic Tongans join up with affiliates of their principal village to stage an elaborate feast of Tongan delicacies, especially roast pig on a spit, and to make speeches and perform dances. For villages on nobles' estates, such as Kolonga - the location of the village day festivity we attended in Otahuhu, South Auckland - the noble and his family are brought over from Tonga to sit at the head table and be part of the official programme. The five images here capture the trans in transnational Tongan life; that is, the methods by which cultural ideas, information and identity transfigure a venue, site and surroundings in the movement from one place to another.

\section{REFERENCES}

Fraser, Nancy (1990) 'Rethinking the public sphere: A contribution to the critique of actually existing democracy', Social Text 25/26: 56-80.

Lee, Helen (2009) 'Introduction', in Helen Lee and Steve Tupai Francis (eds) Migration and Transnationalism: Pacific Perspectives, Canberra: ANU Press, pp. 1-6.

Lilomaiava-Doktor, Sa'iliemanu (2009) 'Samoan transnationalism: Cultivating “home” and "reach"', in Helen Lee and Steve Tupai Francis (eds) Migration and Transnationalism: Pacific Perspectives, Canberra: ANU Press, pp. 57-71.

Nicholls, Walter J., and Justus Uitermark (2016). 'Migrant cities: Place, power, and voice in the era of super diversity’, Journal of Ethnic and Migration Studies 42(6): 877-92. 